\title{
ANALISIS PERBANDINGAN LTE-ADVANCED CARRIER AGGREGATION DEPLOYMENT SCENARIO 2 DAN 5 DI SEMARANG TENGAH
}

\author{
Evan Sigit Kurniawan ${ }^{1}$, Ade Wahyudin ${ }^{2}$, Achmad Rizal Danisya ${ }^{3}$ \\ ${ }^{1,2,3}$ Program Studi S1 Teknik Telekomunikasi, Institut Teknologi Telkom Purwokerto
}

Informasi Makalah

Dikirim, 23 Januari 2019

Direvisi, 9 Agustus 2019

Diterima, 16 Oktober 2019

\section{Kata Kunci:}

LTE-Advanced

Carrier Aggregation

CADS 2

CADS 5

Atoll

\begin{abstract}
INTISARI
Pada tahun 2010 3GPP mengenalkan teknologi LTE-Advanced, teknologi yang mampu memberikan kecepatan datarates hingga 3 Gbps pada sisi downlink dan 1,5 Gbps pada sisi uplink. Salah satu fitur yang menjadi faktor bertambahnya datarates tersebut adalah dengan teknik carrier aggregation. Dalam penelitian ini diimplementasikan 2 skenario yaitu Carrier Aggregation Deployment Scenario (CADS) 2 dan 5 dengan simulasi menggunakan software Atoll 3.3.0. Perancangan dilakukan pada frekuensi $1800 \mathrm{MHz}$ dengan bandwidth $15 \mathrm{MHz}$ dan frekuensi $2300 \mathrm{MHz}$ dengan bandwidth 20 $\mathrm{MHz}$ di Semarang Tengah. Untuk perancangan dilakukan perancangan jaringan baru berdasarkan acuan site eksisting LTE $1800 \mathrm{MHz}$ di Semarang Tengah yang diperoleh dari salah satu subkontraktor telekomunikasi di Indonesia.

Parameter yang dianalisis pada penelitian ini antara lain : RSRP, CINR, user connected dan throughput berdasarkan simulasi menggunakan software Atoll 3.3.0. Untuk perancangan dengan skenario tanpa CA diperoleh mean RSRP sebesar $-84,88 \mathrm{dBm}$, mean CINR sebesar 7,64 dB, rata-rata presentase user connected 99,9 \% dan mean throughput sebesar 833,19 Mbps. Kemudian pada perancangan dengan skenario CADS 2 diperoleh mean RSRP sebesar $75 \mathrm{dBm}$, mean CINR sebesar 19,97 dB, rata-rata presentase user connected $100 \%$ dan mean throughput sebesar 1.152,2 Mbps. Dan pada perancangan dengan skenario CADS 5 diperoleh mean RSRP sebesar $-71,5 \mathrm{dBm}$, mean CINR sebesar 21,89 dB, rata-rata presentase user connected $100 \%$ dan mean throughput sebesar 1.147,3 Mbps. Berdasarkan hasil analisis pada penelitian ini didapatkan hasil perancangan jaringan terbaik yaitu menggunakan skenario CADS 5. Sehingga peracangan jaringan yang paling layak untuk diterapkan di Semarang Tengah yaitu dengan menggunakan perancangan jaringan LTE-Advanced dengan CADS 5.
\end{abstract}

Keyword:

LTE-Advanced

Carrier Aggregation

CADS 2

CADS 5

Atoll

\begin{abstract}
In 2010 3GPP introduced LTE-Advanced technology, a technology capable of providing datarates up to 3 Gbps on the downlink side and 1.5 Gbps on the uplink side. One feature that is a factor in increasing datarates is the carrier aggregation technique. In this study 2 scenarios were implemented, namely Carrier Aggregation Deployment Scenario (CADS) 2 and 5 with simulations using Atoll 3.3.0 software. The design was carried out at $1800 \mathrm{MHz}$ frequency with $15 \mathrm{MHz}$ bandwidth and $2300 \mathrm{MHz}$ frequency with $20 \mathrm{MHz}$ bandwidth in Central Semarang. For the design, a new network design is carried out based on the existing reference site of LTE $1800 \mathrm{MHz}$ in Central Semarang obtained from one of the telecommunications subcontractors in Indonesia.
\end{abstract}

The parameters analyzed in this study include: RSRP, CINR, user connected and throughput based on simulation using Atoll 3.3.0 software. For the design with a scenario without CA, the mean RSRP is $-84.88 \mathrm{dBm}$, the mean CINR is $7.64 \mathrm{~dB}$, the average percentage of users connected is $99.9 \%$ and the mean throughput is 833.19 Mbps. Then in the design with the CADS 2 scenario, the mean RSRP is -75 dBm, the mean CINR is $19.97 \mathrm{~dB}$, the average percentage of users connected is $100 \%$ and the mean throughput is 
1,152.2 Mbps. And in the design with the CADS 5 scenario the mean RSRP is $-71.5 \mathrm{dBm}$, the mean CINR is $21.89 \mathrm{~dB}$, the average percentage of users connected is $100 \%$ and the mean throughput is 1,147.3 Mbps. Based on the results of the analysis in this study the best network design results were obtained using the CADS 5 scenario. So that the most feasible network designation to be implemented in Central Semarang was by using the LTEAdvanced network design with CADS 5.

\author{
Korespondensi Penulis: \\ Evan Sigit Kurniawan \\ Program Studi S1 Teknik Telekomunikasi \\ Institut Teknologi Telkom Purwokerto \\ JL. DI Panjaitan No.128 Purwokerto \\ Email: evansigitk@gmail.com
}

\title{
1. PENDAHULUAN
}

Pengguna layanan teknologi seluler dari tahun ketahun terus meningkat. Sehingga untuk memenuhi kebutuhan trafik layanan, permintaan pelanggan akan kecepatan datarate yang tinggi serta tercapainya kebutuhan Quality of Service (QoS) menjadi salah satu latar belakang pengembangan teknologi Long Term Evolution (LTE). LTE release 8 yang diluncurkan pada tahun 2009 oleh 3rd Generation Partnership Project (3GPP) memiliki kecepatan datarate hingga $100 \mathrm{Mbps}$ pada sisi downlink dan $50 \mathrm{Mbps}$ pada sisi uplink [1]. Namun LTE release 8 ini belum memenuhi spesifikasi International Telecommunication Union (ITU) untuk standar sistem 4G yang terangkum dalam IMT-Advanced [2].

Pada tahun 2010 3GPP mengenalkan teknologi LTE-Advanced, teknologi tersebut mampu memberikan kecepatan datarates hingga 3 Gbps pada sisi downlink dan 1.5 Gbps pada sisi uplink[1]. Salah satu fitur pada teknologi tersebut adalah Carrier Aggregation (CA). CA merupakan sebuah metode penggabungan dua atau lebih component carrier (CC) dengan bandwidth maksimum $100 \mathrm{Mhz}$ sehingga teknologi tersebut diharapkan dapat memenuhi kebutuhan trafik layanan yang tinggi serta menghasilkan kecepatan datarate yang tinggi [1].

Dalam penerapan CA terdapat beberapa jenis implementasi skenario atau biasa disebut Carrier Aggregation Deployment Scenario (CADS) yaitu CADS1, CADS2, CADS3, CADS4 dan CADS5[3]. Dengan adanya CADS tersebut dapat meningkatkan nilai throughput pelanggan pada perancangan ini dikarenakan adanya aggregasi antar bandwidth dan antar frekuensi carrier. Dalam penerapan CADS terdapat dua kombinasi CA yaitu penggabungan dua CC yang sama (intraband) dan penggabungan dua $\mathrm{CC}$ yang berbeda (interband).

Pada penelitian ini menerapkan dua skenario untuk perancangan jaringan LTE-Advanced yaitu CADS2 dan CADS5. CADS2 merupakan skenario yang menerapkan konsep interband, dimana pada penelitian ini akan menggunakan frekuensi yang berbeda yaitu frekuensi $1800 \mathrm{MHz}$ dengan bandwidth 15 MHz (Primary Cell) untuk menyediakan cakupan yang luas dan frekuensi $2300 \mathrm{MHz}$ dengan bandwidth 20 $\mathrm{MHz}$ (Secondary Cell) untuk meningkatkan throughput karena memiliki cakupan yang lebih kecil. CADS5 memiliki konsep skenario yang hampir sama dengan CADS2, hanya saja pada CADS5 terdapat penambahan repeater yang digunakan untuk memperluas cakupan, menguatkan sinyal serta meningkatkan throughput pada area yang yang ditentukan.

Penelitian terkait LTE-Advanced sudah dilakukan oleh beberapa peneliti yaitu Juwi Nanda Sinulinngga pada tahun 2018 membahas mengenai perancangan LTE-advanced release 12 menggunakan teknik carrier aggregation interband. Parameter yang dianalisis pada penelitian tersebut yaitu signal level, CINR, user connected dan throughput. Dari hasil perancangan LTE-Advanced release 12 dengan teknik carrier aggregation interband diperoleh signal level $\geq-80 \mathrm{dBm}$ sebesar $100 \%$, CINR level $\geq 5 \mathrm{~dB}$ sebesar $78.3 \%$, rata-rata presentase user connected $99.61 \%$ dan throughput 2059.14 Mbps [4].

Pada penelitian ini akan membuat peracangan jaringan LTE-Advanced di Semarang Tengah yang merupakan pusat pemerintahan Kota Semarang guna mengoptimalkan jaringan di wilayah tersebut. Berdasarkan latar belakang yang sudah dijelaskan tersebut penulis mangambil judul penelitian "ANALISIS PERBANDINGAN LTE-ADVANCED CARRIER AGGREGATION DEPLOYMENT SCENARIO 2 DAN 5 DI SEMARANG TENGAH". Parameter yang dianalisis pada penelitian ini adalah jumlah kebutuhan site, RSRP, CINR, user connected dan throughput.

Techno Vol. 20, No. 2, Oktober 2019: $77-86$ 


\section{METODOLOGI PENELITIAN}

\subsection{Diagram Alur Penelitian}

Pada penelitian ini dilakukan simulasi perancangan jaringan LTE-Advanced berdasarkan acuan site eksisting LTE $1800 \mathrm{MHz}$ di Semarang Tengah yang diperoleh dari salah satu subkontraktor telekomunikasi di Indonesia. Untuk mendapatkan estimasi jumlah site yang dibutuhkan di Semarang Tengah dapat dilakukan dengan menggunakan perhitungan berdasarkan planning by coverage dan planning by capacity. Kemudian simulasi perancangan jaringan dilakukan dengan menggunakan software Atoll 3.3.0 dengan beberapa skenario seperti pada gambar 1 yaitu skenario tanpa CA, CADS 2 dan CADS 5. Perancangan jaringan LTE tanpa CA hanya dilakukan pada frekuensi $1800 \mathrm{MHz}$ dengan bandwidth $15 \mathrm{MHz}$. Perancangan jaringan LTE-Advanced dengan CADS 2 dan CADS 5 dilakukan pada frekuensi $1800 \mathrm{MHz}$ dengan bandwidth 15 MHz sebagai primary cell dan frekuensi $2300 \mathrm{MHz}$ dengan bandwidth $20 \mathrm{MHz}$ sebagai secondary cell. Yang membedakan antara CADS 2 dan CADS 5 yaitu adanya penambahan repeater pada CADS 5 yang berfungsi untuk memperluas cakupan salah satu frekuensi serta dapat meningkatkan kuat sinyal dan throughput pada area tertentu. Untuk metode penempatan repeater yaitu menggunakan main beam dari transmitter pendonor sebagai jarak minimal penempatan repeater. Parameter yang dianalisis yaitu jumlah site yang dibutuhkan, RSRP, CINR, user connected dan throughput. Pada gambar 3.1 berikut adalah diagram alur penelitian perancangan jaringan LTE dan LTE-Advanced dengan CADS 2 dan CADS 5.

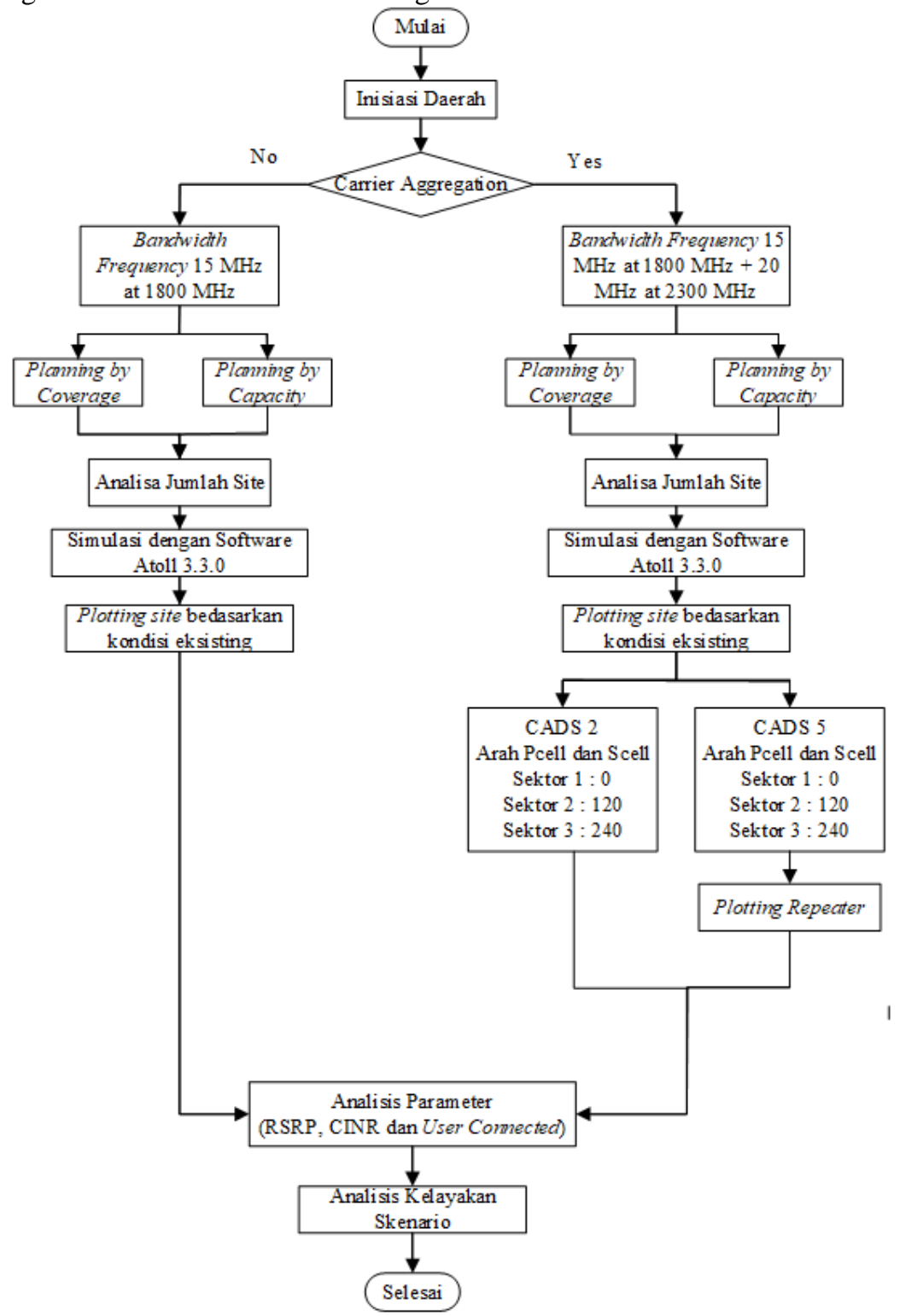

Gambar 1. Diagram alur penelitian

Penelitian ini dilakukan di Semarang Tengah sebagai daerah tinjauan. Semarang Tengah secara astronomis terletak diantara $6^{\circ} 50-7^{\circ} 20$ Lintang Selatan dan $109^{\circ} 50-110^{\circ} 35$ Bujur Timur. Luas wilayah 
Semarang Tengah adalah $6.14 \mathrm{~km}^{2}$ dengan jumlah penduduk adalah 69.711 jiwa dan kepadatan penduduknya mencapai $11.353 \mathrm{jiwa} / \mathrm{km}^{2}$ [5]. Semarang Tengah termasuk dalam kategori daerah urban karena kepadatan penduduknya sudah mencapai jumlah yang sudah ditentukan untuk kategori urban dan daerahnya tidak terdapat wilayah persawahan.

\subsection{Coverage Planning}

Perancangan berdasarkan coverage planning dilakukan untuk mengestimasi jumlah site yang dibutuhkan agar bisa menyediakan layanan untuk semua daerah yang ditinjau. Coverage planning mempertimbangkan Radio Link Budget dan Model Propagasi yang digunakan. Perhitungan Radio Link Budget digunakan untuk memperkirakan redaman maksimum sinyal atau Maximum Allowable Path Loss (MAPL) yang diperbolehkan antara antena UE dengan antena eNodeB. Berikut ini merupakan persamaan untuk mencari nilai MAPL downlink [6] :

$$
\mathrm{MAPL}_{\mathrm{DL}}=\mathrm{EIRP}_{\mathrm{DL}}-\mathrm{S}_{\mathrm{RN} N \mathrm{NLL}}-\mathrm{I}_{\mathrm{Qudoum}}-\mathrm{M}_{\mathrm{SF}}
$$

Untuk menentukan jumlah kebutuhan site digunakan frekuensi $1800 \mathrm{MHz}$ sebagai primary cell karena memiliki radius pancaran sinyal yang lebih jauh. Berikut ini merupakan persamaan Model Propagasi COST231-Hatta dan Standford University Interim (SUI) :

- COST231-Hatta [7]

$\mathrm{PL}=46,3+33,9(\log )-13,82 \log \mathrm{hb}-\mathrm{a}(\mathrm{hm})+(44,9-6,55 \operatorname{loghb}) \log \mathrm{d}+\mathrm{CM}$

- SUI [7]

$$
\mathbf{P L}=\mathrm{A}+10 \gamma \log \left(\frac{\mathrm{d}}{\mathrm{d}_{0}}\right)+\mathrm{X}_{\mathrm{f}}+\mathrm{X}_{\mathrm{h}}+\mathrm{S}
$$

- Luas Sel [8]

Berikut rumus untuk menentukan luas sel dan jumlah sel yang dibutuhkan :

$$
L_{\infty i l}=1,95 \times 2,6 \times d^{2}
$$

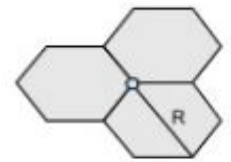

Gambar 2. Sel 3-sectoral

- Jumlah Sel [8]

$$
\text { ILTL cell }=\frac{L_{\text {iusen }}}{L_{\text {well }}}
$$

\subsection{Capacity Planning}

Perancangan berdasarkan capacity planning dilakukan untuk mengestimasi jumlah site yang dibutuhkan untuk melayani jumlah user di daerah tinjauan. Perancangan berdasarkan capacity planning meliputi perhitungan estimasi jumlah pelanggan, kepadatan trafik, kapasitas sel dan perhitungan jumlah sel berdasarkan kapasitas. [9]

Estimasi jumlah pelanggan digunakan untuk mengantisipasi jumlah pelanggan selama periode tersebut. Berikut merupakan persamaan untuk menghitung estimasi jumlah pelanggan dalam jangka waktu tertentu :

$$
\mathrm{U}_{\mathrm{n}}=\mathrm{U}_{0}\left(1+\mathrm{f}_{\mathrm{p}}\right)^{\mathrm{n}}
$$

Untuk mempertahankan kualitas layanan-layanan tersebut perlu dilakukan estimasi nilai throughput yang harus disediakan oleh suatu jaringan. Berikut merupakan rumus untuk menghitung throughput per session :

$$
\text { Throughput/session }=\text { Bearer rate } \times S T \times S R \times\left[\frac{1}{(1-B L E R}\right]
$$

Untuk menghitung single user throughput digunakan persamaan sebagai berikut :

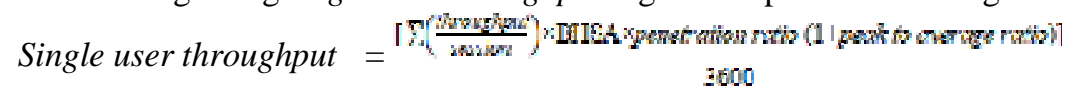

Untuk menghitung kebutuhan throughput suatu jaringan untuk memenuhi permintaan user pada daerah tinjauan digunakan persamaan sebagai berikut :

Techno Vol. 20, No. 2, Oktober 2019: $77-86$ 
Network Throughput $=$ total user number $\mathrm{x}$ DL single user throughput

Agar operator dapat melayani user dengan berbagai jenis layanan, maka suatu jaringan harus mempunyai kapasitas yang dapat mencukupi kebutuhan user. Rumus yang digunaan untuk mencari throughput pada sistem FDD berbeda dengan sistem TDD. Pada sistem FDD cara kerja pengiriman informasi menggunakan 2 frekuensi yang berbeda pada sisi uplink maupun downlink. Sedangkan dalam sistem TDD proses pengiriman informasi dilakukan dengan menggunakan satu frekuensi untuk arah uplink dan downlink. Berikut rumus perhitungan untuk menghitung throughput per cell pada sistem FDD dan TDD [10] :

- Throughput per cell FDD

Throughput $=$ Number of chains $\mathrm{x}$ TB size

- Throughput per cell TDD

DL throughput $=$ Number of chains $\mathrm{x}$ TB size $\mathrm{x}$ (contribution by DL subframe + contribution by DwPTS in SSF)

Untuk menghitung jumlah sel yang dibutuhkan untuk melayani user di daerah tinjauan digunakan persamaan sebagai berikut :

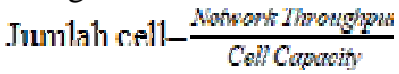

\section{HASIL DAN PEMBAHASAN}

\subsection{Analisis Hasil Perhitungan Planning by Coverage}

Tabel 1. Jumlah site yang dibutuhkan berdasarkan Coverage Planning

\begin{tabular}{|c|c|c|}
\hline & Tanpa CA & Dengan CA \\
\hline Jumlah Site & 1 & 1 \\
\hline
\end{tabular}

Pada tabel 1 menunjukkan bahwa jumlah kebutuhan site hasil perhitungan berdasarkan planning by coverage yaitu 1 site. Acuan jumlah kebutuhan site yang digunakan berdasarkan coverage planning adalah pada frekuensi $1800 \mathrm{MHz}$ sebagai primary cell. Hal tersebut dikarenakan pada frekuensi $1800 \mathrm{MHz}$ memiliki radius pancaran sinyal yang lebih jauh dibanding frekuensi $2300 \mathrm{MHz}$ sebagai secondary cell.

\subsection{Analisis Hasil Perhitungan Planning by Capacity}

Tabel 2. Jumlah site yang dibutuhkan berdasarkan capacity planning

\begin{tabular}{|c|c|c|c|c|c|}
\hline \multirow{2}{*}{ No } & \multirow{2}{*}{ Klasifikasi Daerah } & \multirow{2}{*}{ Daerah Penelitian } & \multirow{2}{*}{$\begin{array}{c}\text { Jumlah } \\
\text { pelanggan LTE }\end{array}$} & & \multicolumn{2}{|c|}{ Jumlah Site } \\
\cline { 5 - 6 } & & & Tanpa CA & Dengan CA \\
\hline 1 & Urban & Semarang Tengah & 17.066 & 1 & DL \\
& & & & & 1 \\
\hline
\end{tabular}

Pada tabel 2 menunjukkan bahwa jumlah site yang dibutuhkan untuk memenuhi kebutuhan user di Semarang Tengah berdasarkan perhitungan capacity planning dengan menggunakan fitur CA maupun tidak dengan CA berjumlah 1 site. Hal tersebut dikarenakan dengan fitur CA dan tidak dengan CA memiliki throughput cell capacity yang besar, jika dikalikan tiga sesuai jumlah sel dalam satu site maka akan samasama memenuhi kebutuhan user LTE di Semarang Tengah.

\subsection{Analisis Hasil Simulasi Reference Signal Received Power (RSRP) Level}
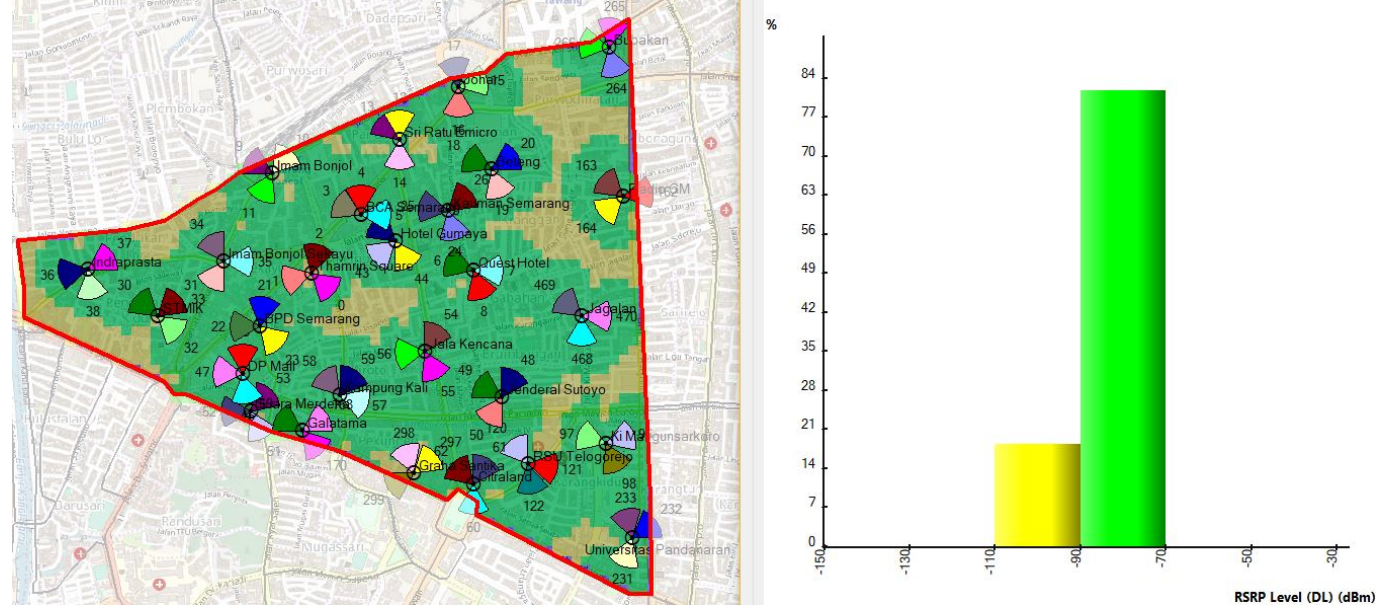
Gambar 3. Persebaran RSRP on map dan presentase RSRP on histogram pada perancangan tanpa CA
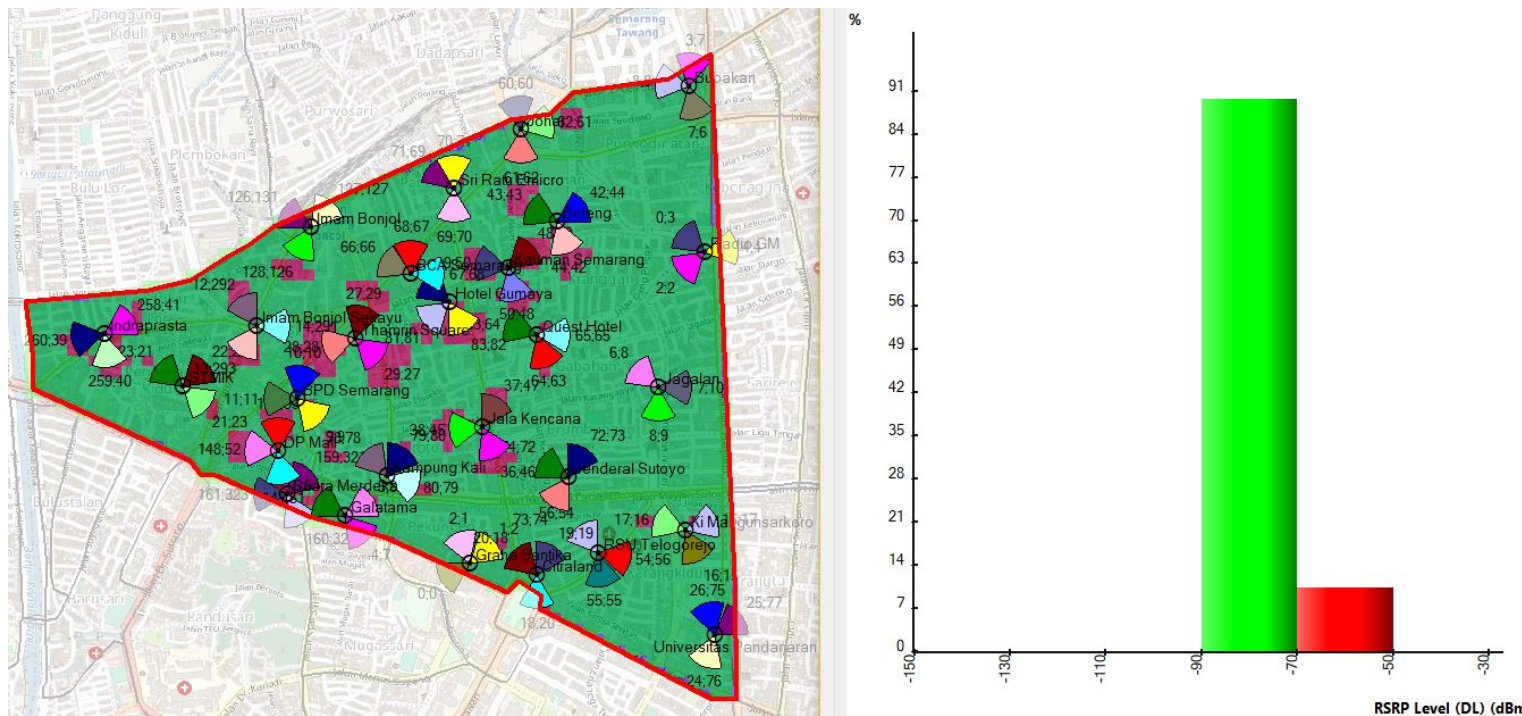

Gambar 4. Persebaran RSRP on map dan presentase RSRP on histogram pada perancangan dengan CADS 2
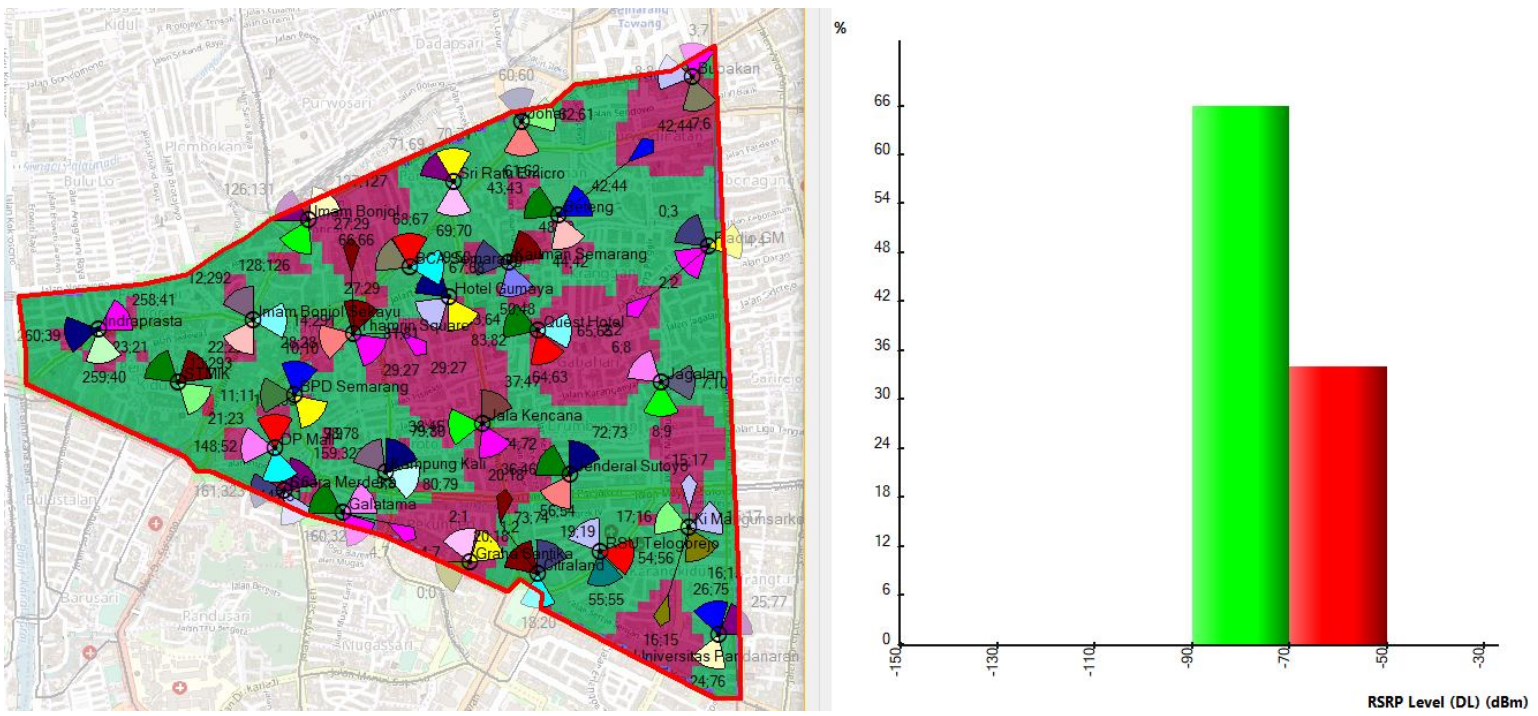

Gambar 5. Persebaran RSRP on map dan presentase RSRP on histogram pada perancangan dengan CADS 5

Pada gambar 3 menunjukkan persebaran dan presentase nilai RSRP pada perancangan jaringan LTE tanpa CA di Semarang Tengah dengan mean RSRP sebesar $-84,88 \mathrm{dBm}$. Kemudian pada gambar 4 menunjukkan persebaran dan presentase nilai RSRP pada perancangan jaringan LTE-Advanced dengan CADS 2 di Semarang Tengah dengan mean RSRP sebesar $-75 \mathrm{dBm}$. Pada gambar 5 menunjukkan persebaran dan presentase nilai RSRP pada perancangan jaringan LTE-Advanced dengan CADS 5 di Semarang Tengah dengan mean RSRP sebesar -71,5 dBm. Dari hasil tersebut didapatkan nilai RSRP terbaik dicapai pada perancangan jaringan LTE-Advanced dengan CADS 5. Hal tersebut dikarenakan adanya teknik CA pada LTE-Advanced yang memiliki 2 serving cell yaitu primary cell dan secondary cell. Sehingga dalam melayani suatu area lebih baik dibanding dengan LTE tanpa CA yang hanya memiliki satu sel. Kemudian pada LTEAdvanced dengan CADS 5 juga terdapat penambahan penguat sinyal (repeater) dibeberapa tempat, dengan metode penempatan repeater yaitu repeater diletakkan pada main beam transmitter donor sebagai jarak minimal peletakkan repeater. Sehingga pada area yang dipancari sinyal dari repeater membuat RSRP nya meningkat dan rata-rata RSRP pada perancangan jaringan LTE-Advanced dengan CADS 5 juga meningkat yang menyebabkan mean RSRP menjadi lebih bagus dari perancangan jaringan LTE-Advanced dengan CADS 2. 


\subsection{Analisis Hasil Simulasi Carrier To Interference And Noise Ratio (CINR) Level}
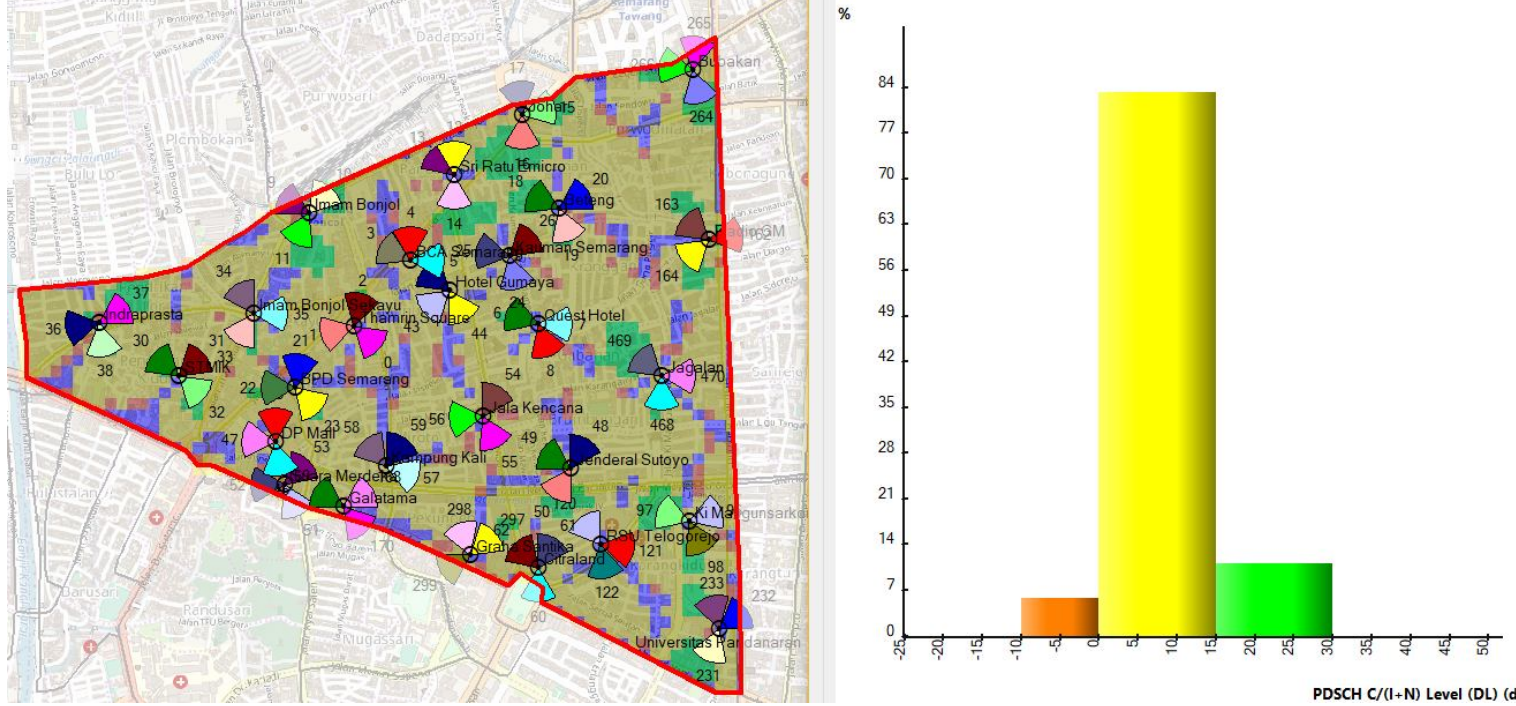

Gambar 6. Kondisi CINR on map dan presentase CINR on histogram pada perancangan tanpa CA
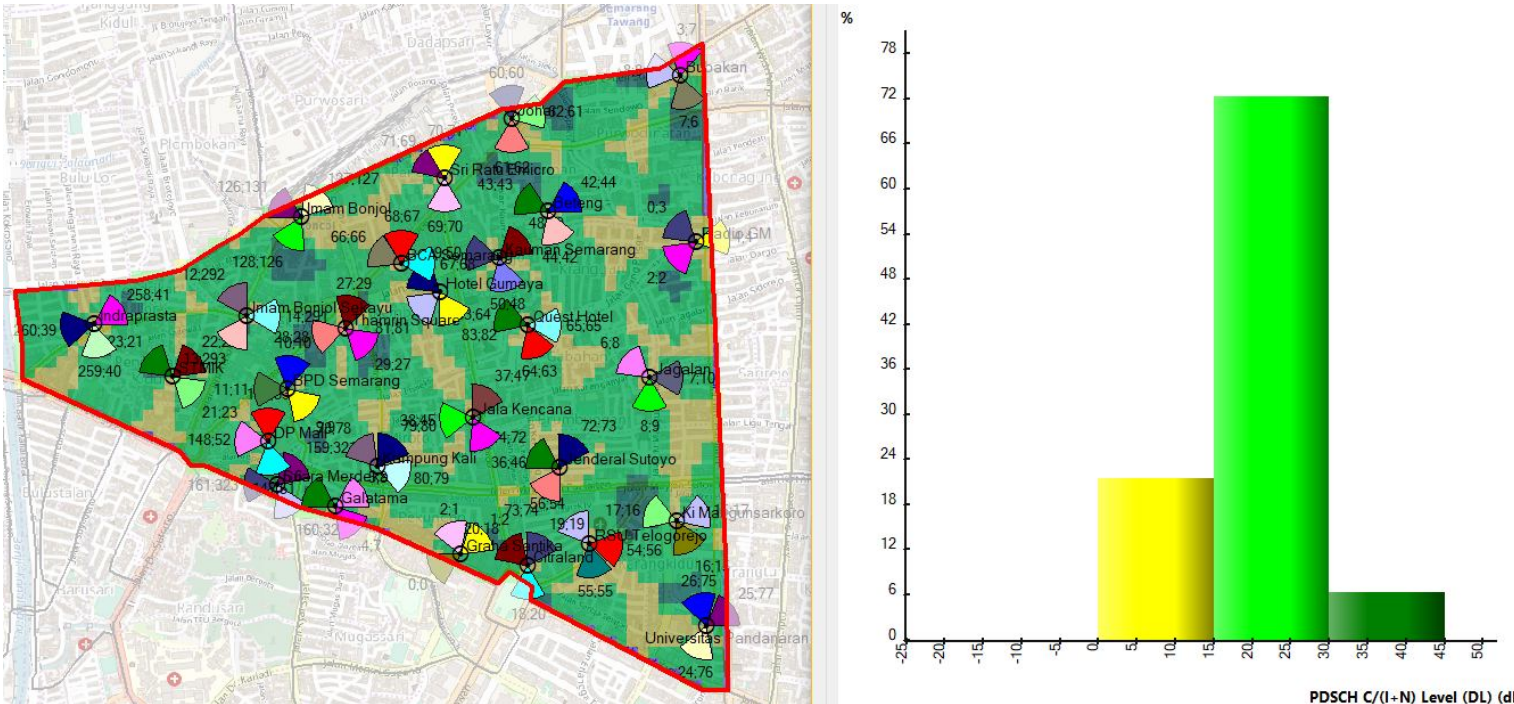

Gambar 7. Kondisi CINR on map dan presentase CINR on histogram pada perancangan dengan CADS 2
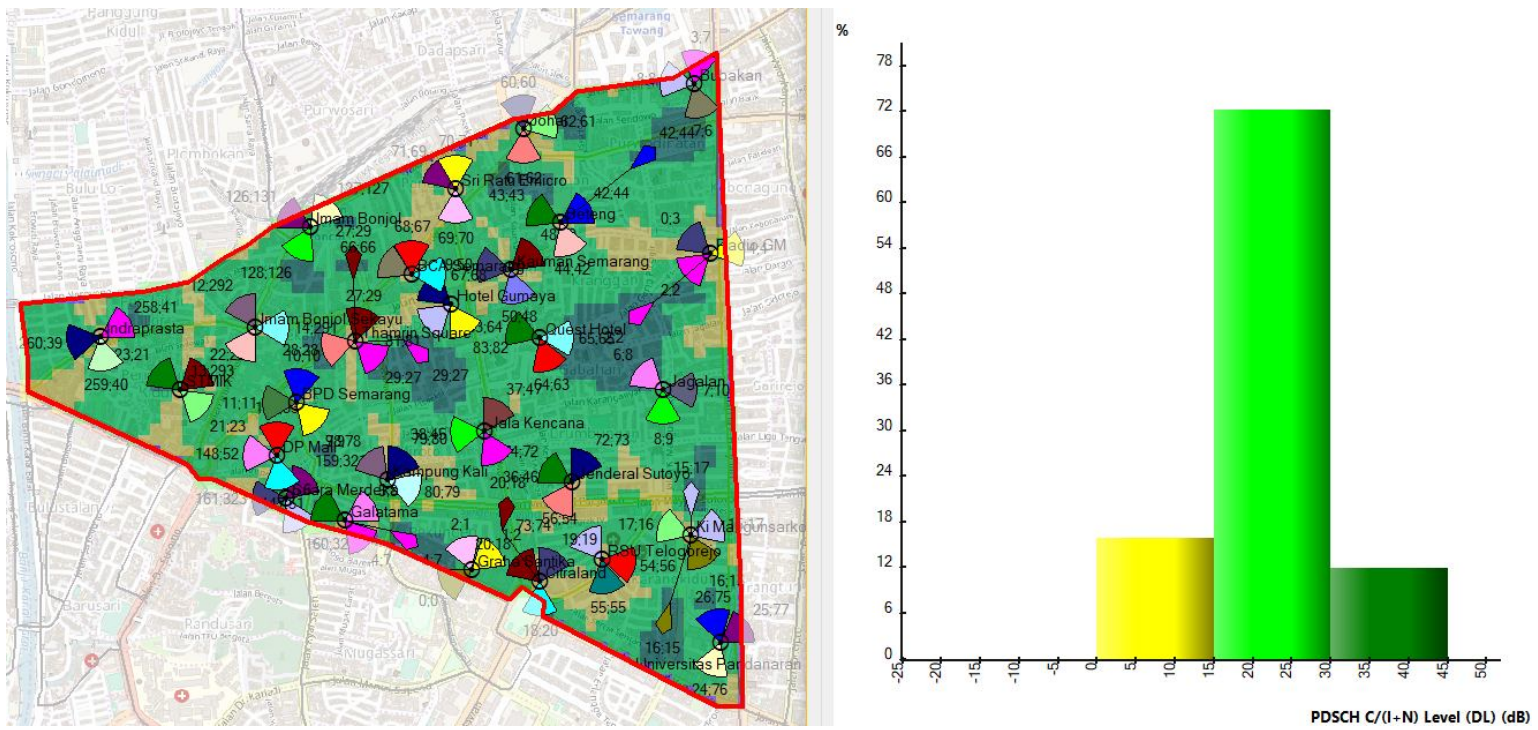
Gambar 8. Kondisi CINR on map dan presentase CINR on histogram pada perancangan dengan CADS 5

Pada gambar 6 menunjukkan persebaran dan presentase nilai CINR pada perancangan LTE tanpa CA di Semarang Tengah dengan mean CINR sebesar 7,64 dB. Kemudian pada gambar 7 menunjukkan persebaran dan presentase nilai CINR pada perancangan jaringan LTE-Advanced dengan CADS 2 di Semarang Tengah dengan mean CINR sebesar 19,97 dB. Kemudian pada gambar 8 menunjukkan persebaran dan presentase nilai CINR pada perancangan jaringan LTE-Advanced dengan CADS 5 di Semarang Tengah dengan mean CINR sebesar 21,89 dB. Dari hasil tersebut didapatkan nilai CINR terbaik dicapai pada perancangan jaringan LTE-Advanced dengan CADS 5. Hal tersebut dikarenakan pada penelitian ini, jaringan LTE-Advanced memiliki 2 sel dengan frekuensi yang berbeda yaitu primary cell dengan frekuensi $1800 \mathrm{MHz}$ dan secondary cell dengan frekuensi $2300 \mathrm{MHz}$, sehingga tidak terjadi interferensi antar carrier dalam sel yang saling tumpang tindih (overlapping) dalam satu transmitter. Akan tetapi interferensi tetap bisa terjadi ketika terdapat overlapping antar sel dengan frekuensi yang sama pada site yang berdekatan. Kemudian pada LTE-Advanced dengan CADS 5 ditambahkan beberapa repeater dengan metode penempatan repeater diletakkan pada area yang terdapat banyak sel dengan frekuensi yang sama yang saling overlapping dengan tujuan untuk menjadikan CINR yang dalam kondisi normal dioptimasi agar menjadi lebih bagus lagi. Frekuensi yang digunakan pada repeater yaitu frekuensi $2300 \mathrm{MHz}$, sehingga ketika sel dengan frekuensi $1800 \mathrm{MHz}$ yang saling overlapping maka dapat didominasi oleh sinyal yang dipancarkan repeater dengan frekuensi yang berbeda yaitu frekuensi $2300 \mathrm{MHz}$. Hal tersebut yang membuat rata-rata CINR meningkat pada perancangan jaringan LTE-Advanced dengan CADS 5 dari perancangan jaringan LTE-Advanced dengan CADS 2.

\subsection{Analisis Hasil Simulasi User Connected dan Throughput}

Tabel 3. Hasil presentase user connected dan throughput

\begin{tabular}{|c|c|c|c|}
\hline Parameter & \multirow{2}{*}{ LTE tanpa CA } & \multicolumn{2}{|c|}{ LTE-Advanced } \\
\cline { 3 - 4 } & & CADS 2 & CADS 5 \\
\hline Presentase User Connected (\%) & 99,9 & 100 & 100 \\
\hline Throughput DL (Mbps) & 833,19 & $1.152,2$ & $1.147,3$ \\
\hline
\end{tabular}

Pada tabel 3 dapat dilihat bahwa pada perancangan tanpa CA mendapatkan hasil presentase user connected sebesar 99,9\% dan throughput sebesar 833,19 Mbps. Pada perancangan dengan CADS 2 mendapatkan hasil presentase user connected sebesar $100 \%$ dan throughput sebesar 1.152,2 Mbps. Pada perancangan dengan CADS 5 mendapatkan hasil presentase user connected sebesar $100 \%$ dan thrpughput sebesar 1.147,3 Mbps. Dari hasil tersebut dapat disimpulkan bahwa presentase user connected terbesar dicapai pada perancangan dengan CADS 2 dan CADS 5. Kemudian throughput terbesar dicapai pada perancangan dengan CADS 2. Hal tersebut dikarenakan kuat sinyal dan kualitas sinyal yang dihasilkan pada jaringan LTE-Advanced lebih bagus dibanding LTE tanpa CA, kemudian kapasitas bandwidth yang disediakan pada jaringan LTE-Advanced juga lebih besar dibanding LTE tanpa CA. Kemudian pada jaringan LTE-Advanced dengan CADS 2 dan CADS 5 juga terdapat perbedaan nilai throughput yang dihasilkan, yaitu skenario CADS 2 lebih besar dibanding CADS 5. Hal tersebut dikarenakan pada CADS 5, repeater yang digunakan tidak memiliki bandwidth sendiri dan untuk kapasitas didapatkan dari kapasitas bandwidth yang dimiliki transmitter pendonor. Sehingga repeater hanya digunakan untuk memperluas cakupan, menguatkan sinyal serta meningkatkan throughput diarea tertentu tanpa menambah kapasitas.

\section{KESIMPULAN}

4.1. Berdasarkan hasil perhitungan coverage planning dan capacity planning, jumlah site yang dibutuhkan untuk meng-cover wilayah Semarang Tengah dan melayani pelanggan LTE pada perancangan tanpa CA dan dengan CA di Semarang Tengah berjumlah 1 site.

4.2. Berdasarkan hasil simulasi nilai RSRP terbaik dicapai pada perancangan jaringan LTE-Advanced CADS 5 dengan mean RSRP -71,5 dBm. Hal tersebut dikarenakan pada LTE-Advanced dengan CADS 5 memiliki 2 serving cell yaitu primary cell dan secondary cell, sehingga dalam melayani suatu area lebih baik dibanding dengan LTE tanpa CA yang hanya memiliki satu sel. Kemudian pada LTE-Advanced dengan CADS 5 juga terdapat penambahan penguat sinyal (repeater) dibeberapa tempat, sehingga pada area yang dipancari sinyal dari repeater membuat RSRP nya meningkat dan rata-rata RSRP pada perancangan jaringan LTE-Advanced dengan CADS 5 meningkat.

4.3. Untuk nilai CINR terbaik dicapai pada perancangan jaringan LTE-Advanced CADS 5 dengan mean CINR 21,89 dB. Hal tersebut dikarenakan pada penelitian ini, jaringan LTE-Advanced dengan CADS 5 memiliki 2 sel dengan frekuensi yang berbeda yaitu primary cell dengan frekuensi $1800 \mathrm{MHz}$ dan secondary cell dengan frekuensi $2300 \mathrm{MHz}$. Kemudian pada LTE-Advanced dengan CADS 5

Techno Vol. 20, No. 2, Oktober 2019: $77-86$ 
ditambahkan beberapa repeater dengan menggunakan frekuensi yang berbeda dari sel yang saling overlapping dengan tujuan untuk menjadikan CINR yang dalam kondisi normal dioptimasi agar menjadi lebih bagus lagi.

4.4. Untuk nilai presentase user connected terbesar dicapai pada perancangan jaringan LTE-Advanced CADS 2 dan CADS 5 yaitu $100 \%$ user dapat mengakses jaringan. Hal tersebut dikarenakan kuat sinyal dan kualitas sinyal yang dihasilkan pada jaringan LTE-Advanced lebih bagus dibanding LTE tanpa CA, kemudian kapasitas bandwidth yang disediakan pada jaringan LTE-Advanced juga lebih besar dibanding LTE tanpa CA.

4.5. Kemudian untuk throughput terbesar dicapai pada jaringan LTE-Advanced CADS 2 dengan throughput sebesar 1.152,2 Mbps. Hal tersebut dikarenakan pada CADS 5, repeater yang digunakan tidak memiliki bandwidth sendiri dan untuk kapasitas didapatkan dari kapasitas bandwidth yang dimiliki transmitter pendonor. Sehingga repeater hanya digunakan untuk memperluas cakupan, menguatkan sinyal serta meningkatkan throughput diarea tertentu tanpa menambah kapasitas yang menyebabkan rata-rata throughput menjadi lebih kecil dari perancangan jaringan LTE-Advanced dengan CADS 2.

\section{DAFTAR PUSTAKA}

[1] A. Hikmaturokhman, L. Wardana, B. Facsi Aginsa, A. Dewantoro, H. Isybel, and M. Gita, 4G Handbook Edisi Bahasa Indonesia Jilid 1. Jakarta Selatan: www.nulisbuku.com, 2014.

[2] I. F. Akyildiz, D. M. Gutierrez-Estevez, R. Balakrishnan, and E. Chavarria-Reyes, "LTE-Advanced and the evolution to Beyond 4G ( B4G ) systems,” Phys. Commun., vol. 10, pp. 31-60, 2014.

[3] S. Pietrzyk, "System-level modelling of HetNets , Carrier Aggregation and Scheduling in MATLAB," in IEEE Globecom, 2015, p. 33.

[4] J. N. Sinulingga, A. Wahyudin, M. A. Amanaf, and S. St, "ANALISIS PERANCANGAN LTE- A DENGAN TEKNIK CARRIER AGGREGATION INTERBAND PADA FREKUENSI $1800 \mathrm{MHz}$ DAN $2300 \mathrm{MHz}$ DI KOTA SEMARANG TENGAH ( STUDY KASUS : PT . TELKOMSEL ) ANALYSIS OF DESIGNING LTEA WITH CARRIER AGGREGATION INTERBAND TECHNIQUE ON FREQUENCY 180," J. Elektro Telekomun. Terap., vol. 5, no. 1, pp. 634-645, 2018.

[5] ～B. P. S. K. SEAMARANG, “Kecamatan Semarang Tengah Dalam Angka 2018,” 2018.

[6] A. Wahyudin and Sakinah, "Perancangan dan Analisa Penggelaran Lte Pada Frekuensi $700 \mathrm{MHz}$ Dengan Metode Adaptif Modulation Coding Untuk Implementasi Digital Dividend Di Wilayah Sub-Urban dan Rural Kabupaten Banyumas,”J. Elektro Telekomun. Terap., vol. 3, no. 2, pp. 342-354, 2016.

[7] Forsk, Atoll 3.3.0 Technical Reference Guide for Radio Networks. Forsk, 2015.

[8] A. Hikmaturokhman, L. Wardana, B. Fernando, G. Mahardhika, and S. Dharmanto, 4G Handbook Edisi Bahasa Indonesia Jilid 2. Jakarta Selatan: www.nulisbuku.com, 2015.

[9] H. Tech, “LTE Radio Network Capacity Dimensioning,” 2013.

[10] S. Rathi, N. Malik, N. Chahal, and S. Malik, "Throughput for TDD and FDD 4G LTE Systems," Int. J. Innov. Technol. Explor. Eng., vol. 3, no. 12, pp. 73-77, 2014. 